\title{
Diagnostics of Major White Grub Species Associated with Potato Crop Ecosystem in Himachal Pradesh, India
}

\author{
Padala Vinod Kumar, K. Sreedevi* and Sukhwinder Singh
}

Division of Entomology, ICAR-Indian Agricultural Research Institute, New Delhi, 110012, India

*Corresponding author

\section{A B S T R A C T}

\begin{tabular}{|l|}
\hline Ke y w or d s \\
Melolonthinae, \\
Rutelinae, \\
Dynastinae, Potato, \\
Himachal Pradesh. \\
\hline Article Info \\
\hline Accepted: \\
26 August 2017 \\
Available Online: \\
10 September 2017 \\
\hline
\end{tabular}

The major white grub species associated with potato crop were surveyed in Himachal Pradesh, India during April to August, 2015. Adults were collected in the vicinity of potato ecosystem by using light traps with black, mercury light sources and manual collection from trees on which they settled for feeding and mating. The survey revealed nine major species of Scarabaeidae of which, four species are melolonthines viz., Brahmina coriacea (Hope, 1837), Holotrichia longipennis (Blanchard, 1850), Holotrichia sikkimensis (Brenske, 1892), Holotrichia seticollis Moser, 1912, four species are rutelines viz., Anomala polita (Blanchard, 1851), Anomala lineatopennis Blanchard, 1851, Anomala dimidiata (Hope, 1831), Anomala propinqua Arrow, 1912 and one species of Dynastinae i.e Phyllognathus dionysius (Fabricius, 1792). Of these, Anomala propinqua Arrow, 1912 is reported for the first time in potato ecosystem. Present studies have brought out illustrative diagnostic keys of white grub species associated with potato crop ecosystem that can be used at field level, where the identification of the species is very important from management point of view.

\section{Introduction}

Scarabaeoidea is one of the largest superfamilies of Coleoptera that include largest family Scarabaeidae. Scarabaeoidea includes approximately 31,000 species worldwide of which the family Scarabaeidae is comprised of 27,800 species (Jameson and Ratcliffe, 2001). Scarabaeidae consist of 13 subfamilies, of which Melolonthinae and Rutelinae are the largest that are widely distributed throughout the world. These beetles are universally known as May beetles or June beetles or cockchafers in their adult stage due to coincidence of their emergence during the month of May/June and the habit of feeding on leaves of plants.
The larvae of these beetles are called white grubs or root grubs as they are subterranean feeders on roots and underground stems of living plants. Lefroy (1906) gave an account on white grubs infesting bajra and other millets in his monumental work 'Indian Insect Pests' and later in 1909 reported that larval stages of Phyllognathus dionysius (F.) (Scarabaeidae: Dynastinae) were destructive to rice crop in his 'Indian Insect Life'. Stebbing (1914) recorded the damage to crops by white grubs from Punjab in India, subsequently Fletcher (1919) reported Serica and Maladera species (Scarabaeidae: Melolonthinae) as serious pests of tea, coffee, cherry, roses. More than 2000 species of 
white grubs are known from the Indian subcontinent, of which over 40 species cause severe damage to a wide range of crop plants (Veeresh et al., 1991).

White grubs are serious pests of various crops such as sugarcane, groundnut, chillies, potato, maize, wheat, barley, jowar, bajra, sesame, sunflower, cotton, tobacco, soybean, brinjal, cucurbit, and bhendi including turf, meadows, lawns and forest trees (Fujiie and Yoloyama, 1996).

The first record of white grubs causing damage to potato in India was from Himachal Pradesh by Sharma and Bhalla (1964). They mentioned two species viz., Brahmina coriacea and Lachnosterna (Holotrichia) longipennis causing damage to several crops including potato in Himachal Pradesh. Misra (1992) recorded 5.7 to 26.5 per cent damage of potato tubers and ginger rhizomes at harvest due to feeding by white grubs that leave large, deep circular holes. Chandel (1992) reported that the tuber damage in potato due to white grubs often exceeds 50 per cent in endemic areas in mid hills of Himachal Pradesh. The problem of white grubs is quite serious in hilly states of India where potatoes are grown during summer season as rainfed crop under long day conditions. Thakur et al., (2008) recorded up to 62.0 per cent tuber damage in potato at Shillaroo in Shimla hills due to B. coriacea. The damage to potato tubers has been reported to vary from 8.5 to 75.0 per cent especially in hilly regions of the country (Chandel et al., 2015). In spite of the seriousness of the problem, the consolidated and systematic work has not been carried out with respect to illustrated identification keys of white grub species associated with potato crop. So, the present study focused on documentation of major white grub species and developing taxonomic descriptions supplemented with illustrations of distinguishing characters that are essential for correct identification of the species to adopt appropriate management strategies.

\section{Materials and Methods}

Surveys were conducted in Solan, Shimla and Shilaroo districts of Himachal Pradesh for the collection of adult white grub species in potato ecosystem during April - August, 2015. Collection of adult beetles was made during the night by using light traps with black and mercury light sources. Since the beetles settle on the leaves of nearby shrubs for feeding and mating after emergence, adults were also collected from the nearby host trees by scouting using the powerful light torches. Generally white grub adults emerge from soil after the first shower of monsoon and it is continued up to August. Hence, the collection of adults was done during the months of April - August, 2015 at fortnightly intervals in the selected locations of the survey areas. The beetles attracted towards the light source were trapped in the collection bucket, placed beneath the light source that contain cotton swab sprinkled with ethyl acetate. Light traps were operated from 6:30 to $10: 00 \mathrm{pm}$. The beetles trapped in the collection bucket were sorted out and transferred to small insect boxes for further processing.

After processing, the specimens were identified up to species level with available keys (Brenske, 1899; Arrow, 1910, 1917; Khan, 1975). Five to ten specimens were studied for each species based on the availability of specimens for the diagnostic characters. The male specimens were studied for all the species collected from potato ecosystems to document the distinguishing characters. The following morphological characters viz., number of segments in antenna, punctations and front margin shape of clypeus; serrations, punctations, anterior 
and posterior angles of pronotum; Striations of elytra; tibial spurs and tarsal claws of legs and phallobase and Parameters of male genitalia were documented. The images of all the diagnostic characters were taken with the help of Leica EZ24HD stereo zoom microscope connected to Leica Application Suite (LAS).

Measurements like length, width of full body and head were taken by using stage and ocular micrometer, after fixing the specimen in horizontal plane. Full body length was measured from tip of the clypeus to the posterior margin of elytra and width was measured at the broadest region of elytra from one margin to other. Similarly, length and width of head was measured from tip of the clypeus to posterior margin of vertex and from both sides of frons, respectively.

\section{Results and Discussion}

The species diversity from potato ecosystem revealed nine major species of white grubs, of which four species of melolonthines viz., Brahmina coriacea (Hope) (Plate 1.1), Holotrichia longipennis (Blanchard) (Plate 1.2), Holotrichia sikkimensis Brenske (Plate 1.3), Holotrichia seticollis Moser (Plate 1.4), four species of rutelines viz., Anomala polita Blanchard (Plate 1.5), Anomala lineatopennis Blanchard (Plate 1.6), Anomala dimidiata (Hope) (Plate 1.7), Anomala propinqua Arrow (Plate 1.8) and one species of Dynastinae viz., Phyllognathus dionysius (F.) (Plate 1.9) were recorded. Among these, A. propinqua is reported for the first time in potato ecosystem. Misra and Chandla (1989) described eight species of white grubs, of which A. dimidiata, A. polita, A. rugosa, $H$. longipennis and $B$. coriacea were the predominant species in hilly tracts where potatoes are grown during summer season as rainfed crop. Chandel et al., (2013) reported destructive species such as $B$. coriacea, $B$. flavosericea, A. dimidiata, Melolontha indica
Hope, $H$. sikkimensis, $H$. longipennis, $H$. seticollis, $P$. dionysius from the potato habitat. Mandeep et al., (2015) recorded five most common species viz., B. coriacea, Adoretus lasiopygus Burmeister, A. lineatopennis, Maladera insanabilis (Brenske) and $H$. longipennis occurring in potato habitat besides apple, pear, walnut, which are in conformity with present studies. The present study furnishes the diagnostic keys to delineate the species for easy identification of the white grub species associated with potato ecosystem, which is important from management point of view.

The diagnostic keys furnished aids in differentiating the subfamilies and further generic and species level. The subfamilies of phytophagous Scarabaeidae can be distinguished based on position of mandibles, labrum, lamellar club, tarsal claws. The species delineation is largely based on antennal characters, clypeal and male genitalia characters. Among melolonthines, three belong to genus Holotrichia, where $H$. longipennis and $H$. sikkimensis are very similar externally and one can distinguish both based on metallic/dull elytra and punctations. Here, male genitalia forms strong basis to differentiate both $H$. longipennis and $H$. sikkimensis, where Parameteres are produced into flap like structures at shoulders in case of $H$. sikkimensis and normal rounded in $H$. longipennis. On the other hand, $H$. seticollis is easily distinguishable from other two species of Holotrichia with distinct black colour body. Similarly rutelines are distinguished based on emarginations of clypeus, pronotal and elytral structures. Hence, the antennal, clypeal and male genitalia characters of species studied are detailed below.

\section{Antenna}

Ten segmented with three segmented lamellate club in Melolonthinae, where length 
of the club is relatively smaller than funicular segments in $B$. coriacea (Plate 2.1), $H$. longipennis (Plate 2.2), H. sikkimensis (Plate 2.3) and $H$. seticollis (Plate 2.4), Antenna nine segmented with three segmented club in Rutelinae, relatively longer than funicular segments in species, A. polita (Plate 2.5), A. lineatopennis (Plate 2.6), A. dimidiata (Plate 2.7), A. propinqua (Plate 2.8) and in $P$. dionysius antennal club is equal to the funicular segments in length (Plate 2.9).

\section{Clypeus}

Clypeus deeply emarginated in B. coriacea (Plate 2.10), slightly in $H$. longipennis (Plate 2.11), $H$. sikkimensis (Plate 2.12) and $H$. seticollis (Plate 2.13), transversely rectangular, margins strongly reflexed and angles round in A. polita (Plate 2.14), broad and almost straight in the middle, lateral margins straight, front angles, front margins slightly raised in A. lineatopennis (Plate 2.15), slightly rectangular in $A$. dimidiata (Plate 2.16), transverse with front margin slightly rounded, front angles rectangular in $A$. propinqua (Plate 2.17), rounded, mandibles expanded sidewards to clypeus in $P$. dionysius (Plate 2.18).

\section{Male genitalia}

\section{Brahmina coriacea}

Phallobase elongated, constricted medially on both sides. Parameteres symmetrical, elongated, immovable, broad at base, curved at apex with blunt tip (Plate 3.1).

\section{Holotrichia longipennis}

Phallobase extended round at base expanded outwardly. Parameters symmetrical, immovable, elongated and strongly bent downwards at apex, united and broad at base, strong chitinized process arise at apical region of phallobase (Plate 3.2).

\section{Holotrichia sikkimensis}

Phallobase broad at base, elongated. Parameteres symmetrical, immovable, elongated and strongly bent downwards and pointed at apex, produced into flap like structures at shoulders. At apex of phallobase an elongated, blunt, chitinized process extended up to apex of Parameteres (Plate 3.3).

\section{Holotrichia seticollis}

Phallobase broad, extended, small depression at apex, attachment between phallobase and Parameteres distinct. Parameteres symmetrical, immovable, each with a chitinized processes, wide apart with two distinct spines at its apex (Plate 3.4).

\section{Anomala polita}

Phallobase wider at base, narrowed towards apex, the attachment between phallobase and Parameteres distinct, slightly curved in middle.

Parameteres are symmetrical separated in middle with distinct spines either side (Plate 3.5).

\section{Anomala lineatopennis}

Phallobase uniform width throughout length, curved. Parametere asymmetrical, left Parametere broad, right Parametere narrow and elongated, sickle like chitinized process at junction of phallobase and Parametere (Plate 3.6).

\section{Anomala dimidiata}

Phallobase elongated, broad at base, slightly narrowed towards apex, attachment between phallobase and Parameteres distinct. Prameres symmetrical, slightly overlapped at base (Plate 3.7). 
Plate.1 1-9 Habitus. 1. B. coriacea, 2. H. longipennis, 3. H. sikkimensis, 4. H. seticollis, 5. A. polita, 6. A. lineatopennis, 7. A. dimidiata, 8. A. propinqua, 9. P. dionysius
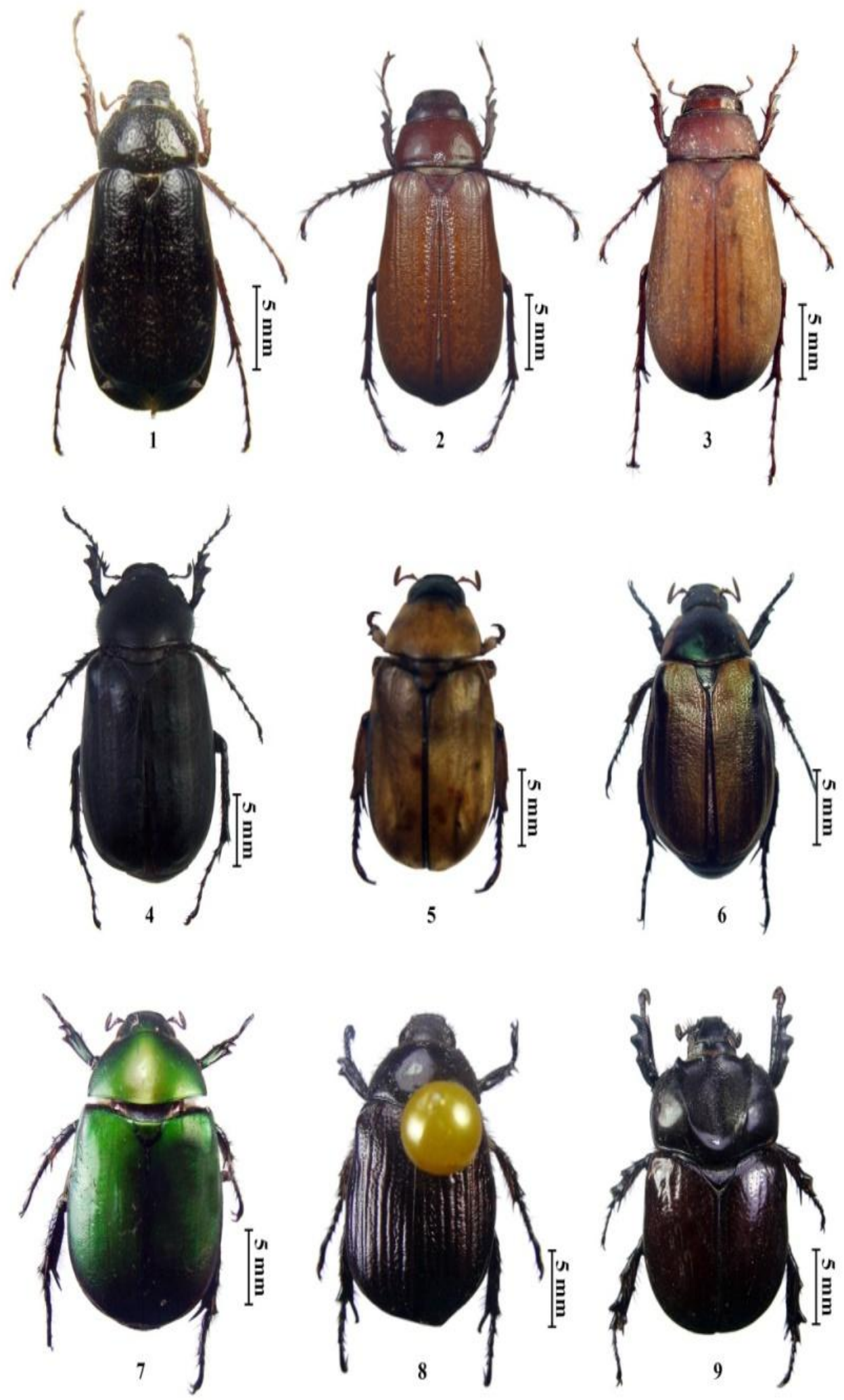
Plate.2 1-9 Left antenna. 1. B. coriacea, 2. H. longipennis, 3. H. sikkimensis, 4. H. seticollis, 5. A. polita, 6. A. lineatopennis, 7. A. dimidiata, 8. A. propinqua, 9. P. dionysius ; 9-18 Clypeus and frons. 10. B. coriacea, 11. H. longipennis, 12. H. sikkimensis, 13. H. seticollis, 14. A. polita, 15. A. lineatopennis, 16. A. dimidiata, 17. A. propinqua, 18. P. Dionysius
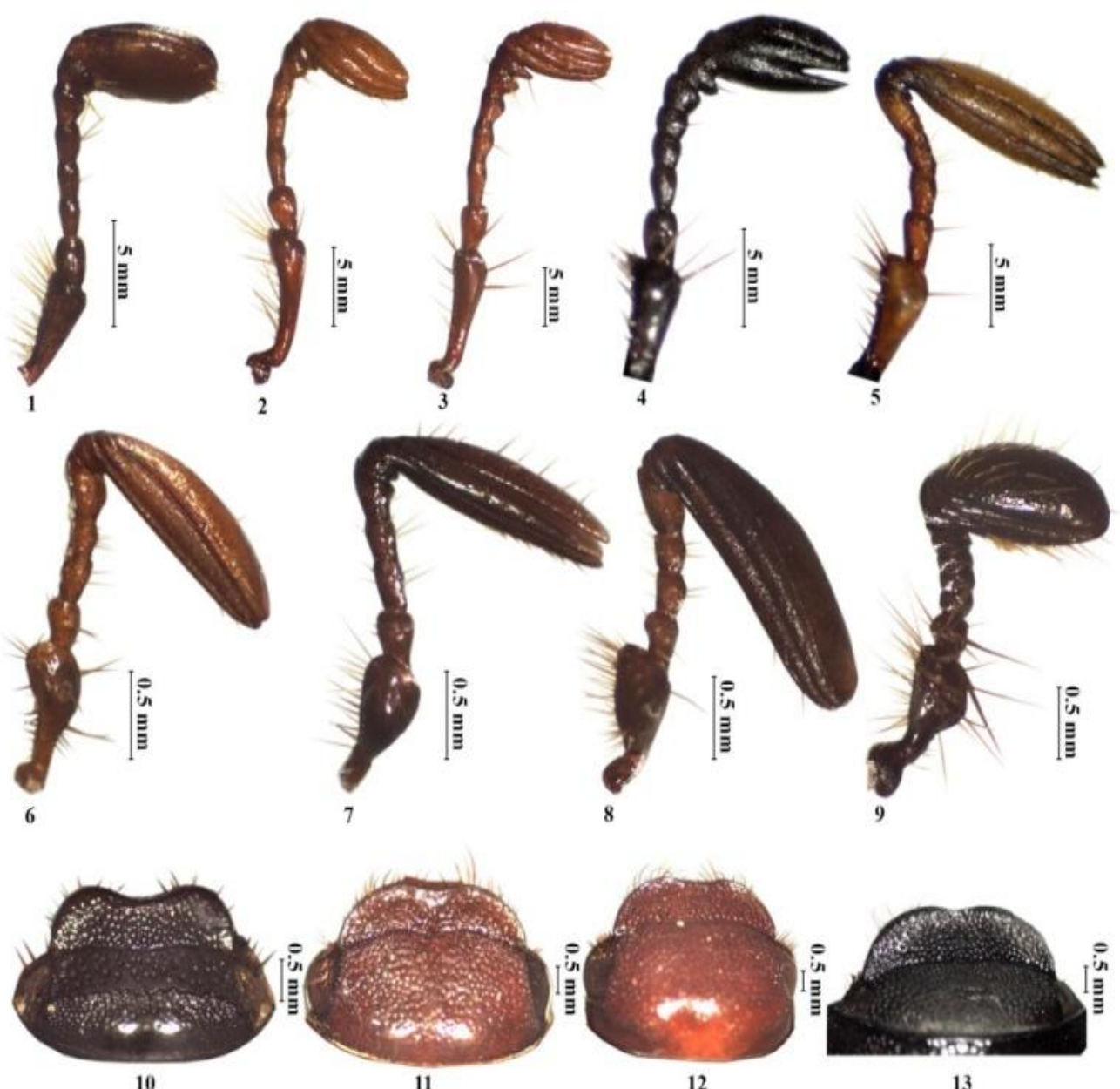

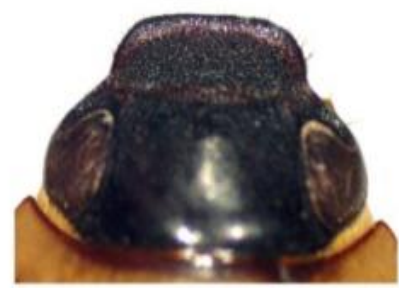

14

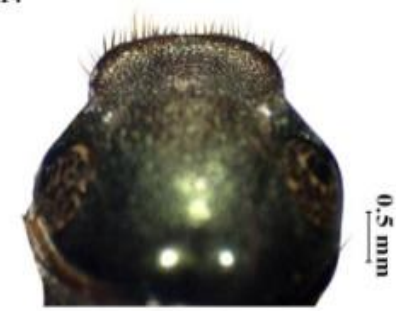

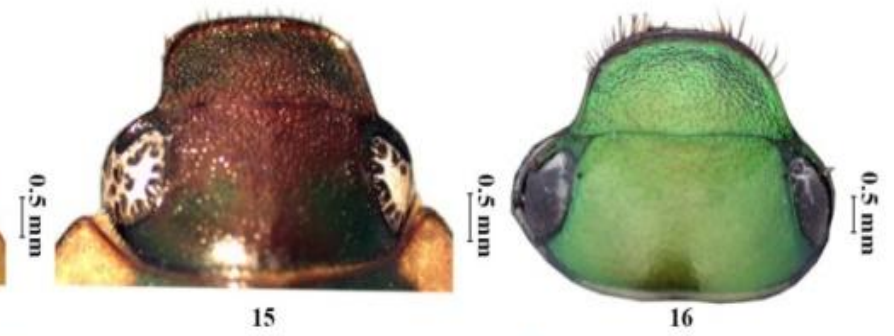

17

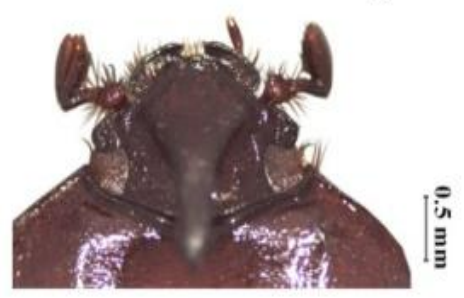

18 
Plate.3 1-9 Male genitalia. 1. B. coriacea, 2. H. longipennis, 3. H. sikkimensis, 4. H. seticollis, 5. A. polita, 6. A. lineatopennis, 7. A. dimidiata, 8. A. propinqua, 9. P. dionysius

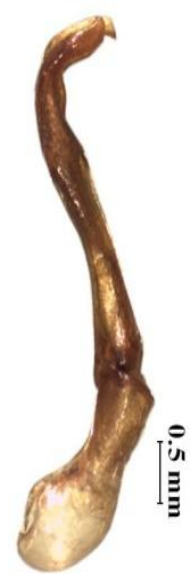

1a

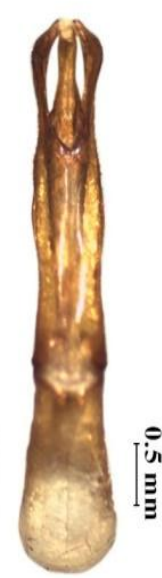

$1 \mathbf{b}$

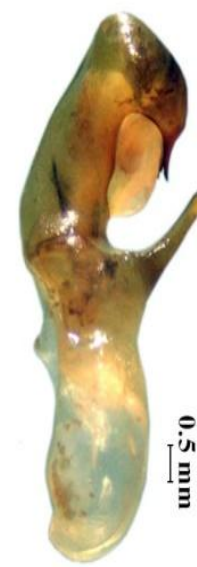

2a

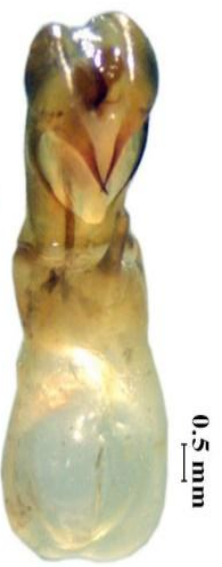

$2 \mathrm{~b}$

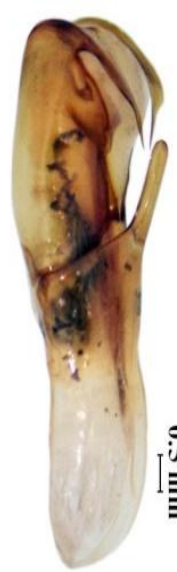

$3 a$

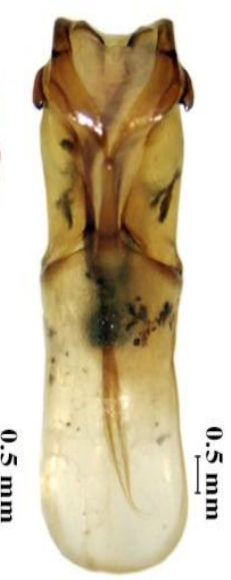

$3 b$

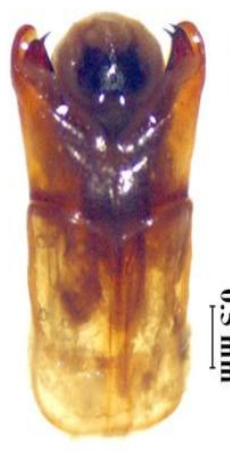

$4 a$

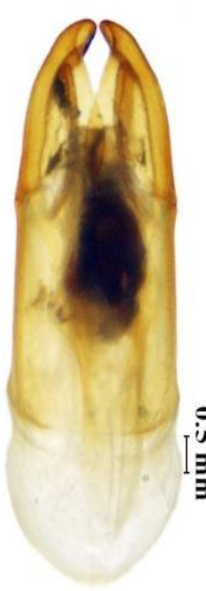

7a

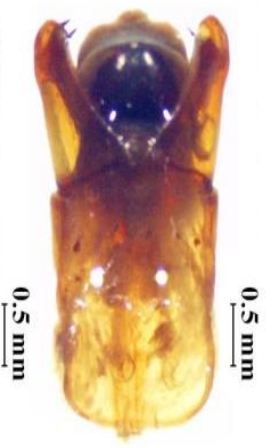

$4 b$

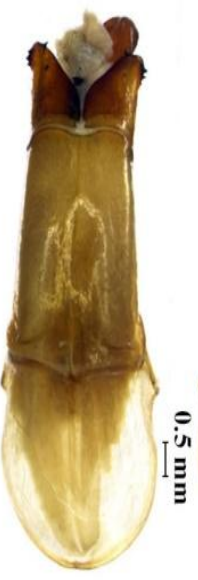

5

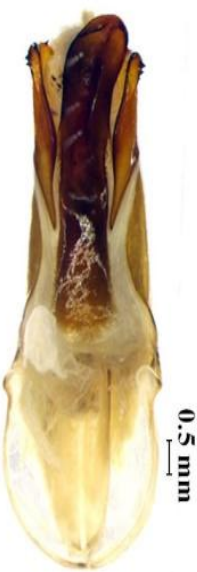

$5 \mathrm{~b}$

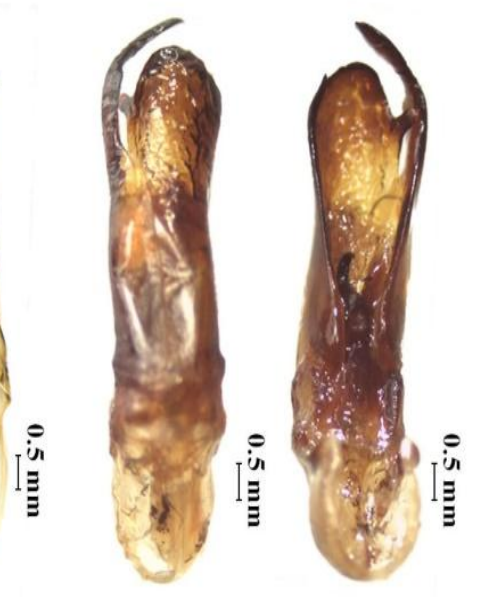

$6 b$

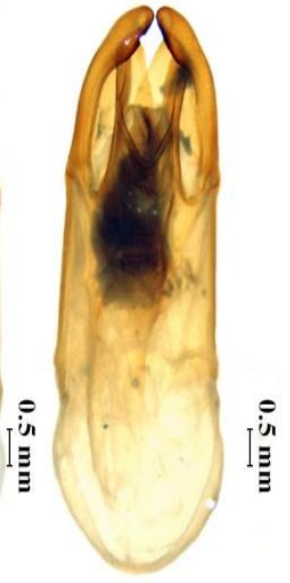

$7 b$

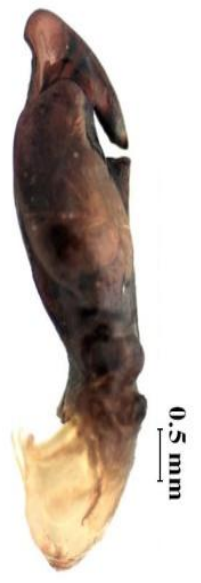

8

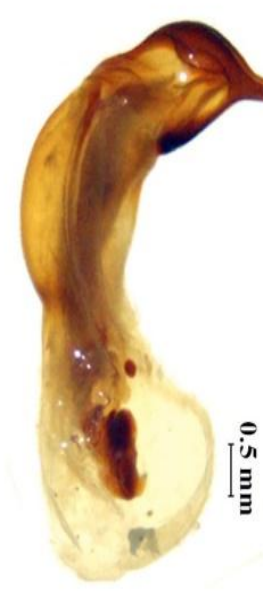

9a

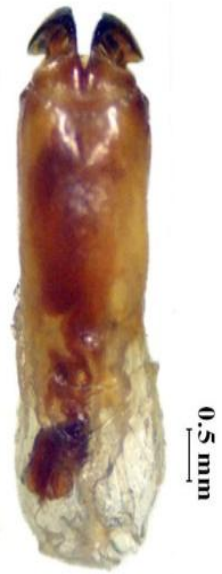

9b 
Plate.4 Distinguishing characters of white grub species associated with potato

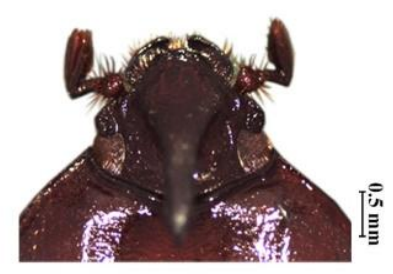

1

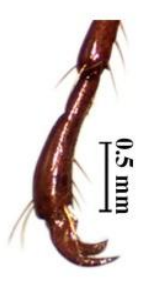

5

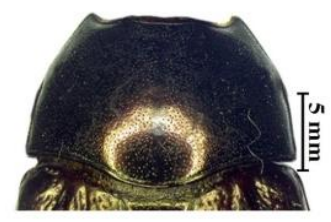

9
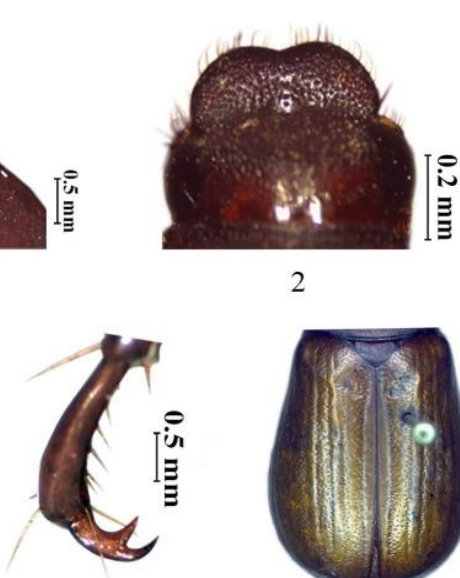

6

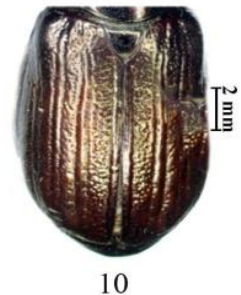

2

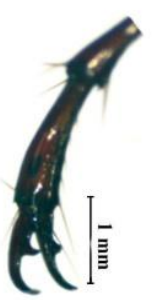

3

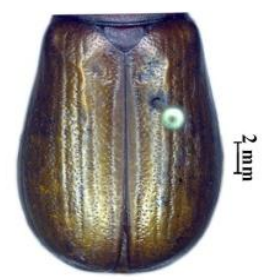

7

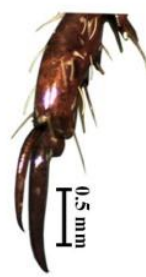

4

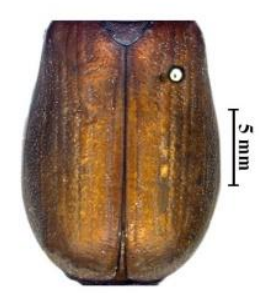

8

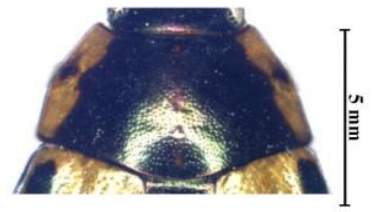

11

\section{Phyllognathus dionysius}

Phallobase broader at base narrow towards middle, curved at middle, symmetrical Parameteres arch like in the middle, slightly pointed at apex (Plate 3.9).

Since Anomala propinqua is reported for the first time in potato ecosystem, brief description of this species furnished along with the diagnostic keys for major species associated with potato ecosystem.

Anomala propinqua Arrow, 1912

\section{Material examined}

INDIA: Himachal Pradesh: Shimla-Kufri (31 $\left.05^{\prime} 52.06^{\prime \prime} \mathrm{N}, 7^{\circ} 16^{\prime} 04.38^{\prime \prime} \mathrm{E}\right), 12{ }^{\wedge} 8$, 12.V.2015, Coll. K. Sreedevi.
Male

Body slightly elongated and broadest at extremity and convex measuring $16 \mathrm{~mm}$ length, $9 \mathrm{~mm}$ breadth, frons and clypeus coppery, slightly metallic, elytra, legs coppery.

\section{Head}

Length $2 \mathrm{~mm}$, breadth $3.4 \mathrm{~mm}$, rugose and opaque. Clypeus transverse with front margin slightly rounded, front angles rectangular, dark brown, shiny appearance with fine shollow punctations (Plate 2,17), vertex with dense punctations at sides, sparsely at posterior median line. Antenna nine segmented with three segmented club, longer than funicular segments (Plate 2,8). 


\section{Thorax}

Pronotum length $3.1 \mathrm{~mm}$, breadth $6 \mathrm{~mm}$, smooth at sides, anterior margin slightly curved in the middle, posterior margin bow shaped, anterior angles acute, posterior angles obtuse, minutely punctured, punctations sparse in the middle, dense at the side, base of the pronotum completely margined. Scutellum finely punctated, broad at anterior, acute at posterior and having short linear impression on both sides. Elytra with deep sutural stria and elevated costa and four paired stria enclosing elevated costa and intervening spaces flat and strongly, irregularly punctured, with deep and fine puncture, two hind tibial spurs on one side of first tarsal segment, front and middle leg claws unequal, larger claw clefted, hind tarsal claws unequal, not clefted.

\section{Male genitalia}

Phallobase broad and less sclerotized at base, the attachment between Parameteres and phallobase not clear, prameres symmetrical, one chitinized structure reflexed backward (Plate 3, 8).

\section{Diagnostic keys for species delineation}

The important characters for distinguishing the species have been documented and furnished here with for easy identification of the white grub species associated with potato ecosystem.

\section{Diagnostic keys for species delineation}

The important characters for distinguishing the species have been documented and furnished here with for easy identification of the white grub species associated with potato ecosystem. 1. Mandibles expanded sidewards to clypeus, tarsal claws simple (Plate 4.1) ..Dynastinae, Phyllognathus dionysius (F.)

- Mandibles not visible from above, fused with clypeus, tarsal claws variable (Plate 4.2) Melolonthinae 3

2. The tarsal claws equal (Plate 4.3)

- The tarsal claws unequal or asymmetrical (Plate 4.4) ......................... Rutelinae 6 -The tarsal claws dentate, thoracic sternites less hairy (Plate 4.6) $\ldots \ldots \ldots \ldots \ldots \ldots \ldots \ldots \ldots \ldots \ldots$ 4. Medium sized body, with distinct black colour Holotrichia seticollis Moser

- Medium to large size body with testaceus brown colour ................................. 5

5. Elytra shiny, striate with close punctations (Plate 4.7) ...Holotrichia longipennis (Blanchard) -Elytra dull, striate with sparse punctations (Plate 4.8)..........Holotrichia sikkimensis Bresnke 6. Hind legs not extremely massive, base of the pronotum completely margined (Plate 4.9) .................................................................................

- Hind legs extremely massive, base of the pronotum not completely margined.................8

7. Front margin of clypeus not excised, hind tibia and tarsus slender Anomala polita Blanchard

- Metasternum clothed with thick hair, scutellum grooved on each side, brownish beetle, intervals of elytra dissimilar (Plate 4.10). Anomala propinqua Arrow

8. Green coloured beetle, large sized, legs on lower surface not uniform deep green, elytra broadest behind middle. Anomala dimidiata (Hope) - Metallic straw colour, pronotum with dark black patch, shoulders of elytra with black sutural line, vanishing posteriorly (Plate 4.11). Anomala lineatopennis Blanchard 
Potato is major staple crop grown in the hilly tracts of country and white grubs are becoming serious biotic stress limiting the yield of the crop in recent past. So, the present study documented the white grub species that are major pests of potato furnishing the distinguishing characters to enable the species identification, which is crucial for adoption of management strategies.

\section{Acknowledgements}

The authors are thankful to The Director, Joint Director (Res.), Dean \& Joint Director (Education), ICAR-Indian Agricultural Research Institute, New Delhi for the facilities. Also authors thank Dr. Chitra Srivastava, Head, Dr. Subash Chander, Professor, Division of Entomology, ICARIARI, New Delhi for facilitating the postgraduate and laboratory work during the research.

\section{References}

Arrow, G. J., 1910. Lamellicornia I: Cetoniinae and Dynastinae. In: The Fauna of British India, Including Ceylon and Burma, Thacker Spink and Co., Calcutta, pp. 322.

Arrow, G. J., 1917. Lamellicornia II: Rutelinae, Desmonycinae, Euchirinae. In: The Fauna of British India, Including Ceylon and Burma, Thacker Spink and Co., Calcutta, pp. 387.

Brenske, E., $1899 . \quad$ Diagnoses Melolonthidarum novarum ex India Orientali, Indian Museum Notes, 4: 176179.

Chandel, R. S., 1992. Bioecology and control of Brahmina coriacea (Hope) Ph. D. Thesis, Department of Entomology and Apiculture, Dr. YSP, University of Horticulture and Forestry, Nauni, Solan, Himachal Pradesh, India pp. 170.

Chandel, R. S., Chandla, V. K., Verma, K. S. and Pathania, M. 2013. Insect pests of potato in India: biology and management. In: Giordanengo $\mathrm{P}$, Vincent $\mathrm{C}$ and Alyokhin A (eds) Insect pests of potato: global perspectives on biology and management, Academic Press Elsevier Inc. pp 227-270.

Chandel, R. S., Pathania, M., Verma, K. S., Bhatacharyya, B., Sumit, V. and Kumar, V. 2015. The ecology and control of potato white grubs of India. European Association for Potato Research, DOI 10.1007/s11540-0159295-3.

Fujiie, A., and Yoloyama, T. 1996. Improvement and use of Metarhizium anisopliae for controlling Anomala cuprea. In: Proceedings of the international symposium on the use of biological control agents under Integrated Pest Management. Food and Fertilizer Technology Centre, Republic China Taiwan. FFTC Book series no.47, pp. 61-69.

Jameson, M. L., and Ratcliffe, B. C. 2001. Scarabaeoidea: Scarabaeoid beetles (=Lamellicornia) (http://www.museum. unl. edu/ research/ entomology/Guide/ Scarabaeoidea /Scarabaeoidea- pages /Scarabaeoidea-Overview/

Scarabaeoidea O. html). In, B. C. Ratcliffe and M. L. Jameson (eds.), 2012. Generic Guide to New World Scarab Beetles. (Accessed on 17-22014).

Khan, K. M., 1975. Studies on Indian Melolonthinae (Coleoptera: Scarabaeidae). Thesis submitted towards Doctoral degree to Indian Agricultural Research Institute, New Delhi, pp. 66-114.

Mandeep, P., Chandel, R. S., Verma, K. S. and Mehta, P. K. 2015. Diversity and population dynamics of phytophagous scarabaeid beetles (Coleoptera: Scarabaeidae) in different landscapes of 
Himachal Pradesh, India. Arthropods, 4(2): 46-68.

Misra, S. S., 1992. White grub, Holotrichia coriacea (Hope) infesting ginger rhizomes in Himachal Pradesh. Journal of Insect Science, 5: 96.

Misra, S. S., and Chandla, V. K. 1989. White grubs infesting potatoes and their management. Journal of Indian Potato Association, 16(1-2): 29-33.

Sharma, P. L., and Bhalla, O. P. 1964. A survey study of insect pests of economic importance in Himachal Pradesh. Indian Journal of Entomology, 26: 318-331.

Stebbing, E. P., 1914. Indian forest insects of economic importance, Coleoptera, Chapter VI, Lamellicornia: Scarabaeidae. Eyre and Spottis Woode
Ltd, pp.648

Thakur, Y., Sharma, A. K, Dhiman, K. R and Chandla, V. K. 2008. Management of white grub, Brahmina coriacea (Hope) in potato (Solanam tuberosum) fields of Fagu (Shimla hills). In: IInd Congress on Insect Science, February 21-22, PAU, Ludhiana. pp. 232.

Veeresh, G. K., Kumar, A. R. V., Ali, M. T. M. 1991. Biogeography of pest species of whitegrubs of Karnataka. In: Veeresh GK, Rajagopal D, Viraktamath CA (Eds) Advances in management and conservation of soil fauna. Oxford and IBP Publishing Company Pvt. Ltd., Bangalore, pp 191-198.

\section{How to cite this article:}

Padala Vinod Kumar, K. Sreedevi and Sukhwinder Singh. 2017. Diagnostics of Major White Grub Species Associated with Potato Crop Ecosystem in Himachal Pradesh, India. Int.J.Curr.Microbiol.App.Sci. 6(9): 2545-2555. doi: https://doi.org/10.20546/ijcmas.2017.609.313 